\title{
Correction to: The Hijab as a Metaphor for Otherness and the Creation of an Ineffable "Third Space"
}

\author{
Kamakshi P. Murti ${ }^{1,2}$ (D) \\ Published online: 19 October 2019 \\ (C) Springer Nature Switzerland AG 2019
}

\section{Correction to: Journal of Dharma Studies (2019) 1:269-285 https://doi.org/10.1007/s42240-019-00022-5}

Following the publication of this article [1], it came to my attention that I unintentionally neglected to acknowledge the following sources. The transcript of the interview with the 50-year-old woman and her relatives was previously published in my book [2]. I would also like to highlight that my anecdote in paragraph 2 of the section "Islamophobia in the Twenty-first Century" was also copied verbatim from my book $[2]$.

Furthermore, in paragraph 5 of the section "Interviews with Turkish and German Muslims," where I had referenced Twist (2015) [3], I should have acknowledged that the original point was made by Riem Spielhaus (2006) [4] and was only quoted by Joseph Twist. As such, the sentence should read as follows:

As Spielhaus (2005) points out, and as later quoted by Twist (2015), this process began after 2000 when Germany's citizenship laws changed from jus sanguinis, i.e., citizenship through parents or ancestors, to incorporate an element of jus soli, i.e., birthright citizenship (Twist 2015).

Lastly, while the ideas related to Şenocak and Sufism presented in the section "Zafer Şenocak's 'Ineffable Third Space'" are based on my own extensive research on the topic, I would like to acknowledge the similarities with some of the ideas explored by Joseph Twist [3].

The online version of the original article can be found at https://doi.org/10.1007/s42240-019-00022-5

Kamakshi P. Murti

1 Middlebury College, Middlebury, VT, USA

2 Fairfax, USA 
[1] Murti, K.P. (2019). The hijab as a metaphor for otherness and the creation of an ineffable "third space". Journal of Dharma Studies 1(2), 269-285 1: 269. https://doi. org/10.1007/s42240-019-00022-5

[2] Murti, K. (2013). To veil or not to veil: Europe's shape-shifting 'other'. Bern, Switzerland: Peter Lang International.

[3] Twist, J. (2015). From Gastarbeiter to Muslim: cosmopolitan literary responses to post-9/11 Islamophobia. (A thesis submitted to the University of Manchester for the degree of Doctor of Philosophy in the Faculty of Humanities) (p. 5). Manchester, U.K.: University of Manchester, School of Arts, Languages and Cultures.

[4] Spielhaus, R. (2006). Religion and identity: how Germany's foreigners have become Muslims. Internationale Politik, 8.2: 17-23

Publisher's Note Springer Nature remains neutral with regard to jurisdictional claims in published maps and institutional affiliations. 